\title{
Morphological and Cultural Characterization of Isolates of Alternaria sesami Causing Sesame Leaf Blight
}

\author{
Vulimiri Jyothsna*, V. Prasanna Kumari, V. Manoj Kumar and B. Sreekanth \\ *Department of Plant Pathology, Agricultural College, Bapatla 522 101, A.P, India \\ *Corresponding author
}

\section{A B S T R A C T}

\section{Key w o r d s \\ Alternaria sesami, Blight, Variation, Cultural, Morphological \\ Article Info \\ Accepted: \\ 15 October 2018 \\ Available Online: \\ 10 November 2018}

\begin{abstract}
Diseased sesame samples were collected from the major growing regions of Andhra Pradesh for molecular and cultural characterization of Alternaria sesami. The collected isolates were characterized based on their conidial length, breadth and beak length and cultural characters (colour of the mycelium, growth on the PDA medium). Of the 12 isolates, most of the isolates were white in their colony colour which later turned into grayish brown, while a few isolates were brown with fluffy growth at the centre. After seven days of incubation highest mycelial growth was observed in NP 2 isolate $(5.28 \mathrm{~cm})$ isolate which was followed by EL 2, NAR $1(5.27 \mathrm{~cm})$. Average conidial size of the $A$. sesami is $24.88-34.64 \mu \mathrm{m} X 9.61-12.13 \mu \mathrm{m}$ with beak length of $5.12-8.32 \mu \mathrm{m}$ and no. of horizontal and vertical septa varied from $2.76-3.82$ and 1.31 - 1.76 respectively.
\end{abstract}

\section{Introduction}

Sesame (Sesamum indicum L.) is commonly known as "Till is one of the short duration crop grown throughout the year. Globally, in India sesame was cultivated in area (18.93 lakh ha) and production (413 $\left.\mathrm{kg} \mathrm{ha}^{-1}\right)$. India also has global market for white seeded types. In Andhra Pradesh, it occupies an area of 0.61 lakh ha with an annual production of 0.20lakhtonnes and with an average productivity of $321 \mathrm{~kg} \mathrm{ha}^{-1}$ (Department of Agriculture, Cooperation \& Farmers Welfare, GOI, 2016-17). Sesamum is attacked by several infectious plant pathogens which are responsible for major damaging factor to crop plants. Among important sesame diseases, Alternaria leaf spot is prevalent in all the sesame growing areas of the world and it is also reported in Kenya, Ethiopia, El-Salvador, Nigeria, India and USA (Verma et al., 2005; Ojiambo et al., 2003; Kolte, 1985; Bhale et al., 1998).

Alternaria sesami is the incident of the sesame leaf blight disease is a highly variable pathogen which can cause seed rot, pre and post mergence losses, stem rot and leaf spots. It attacks seedlings, stems of young plants, leaves and pods of Sesamum indicum causing considerable damage to plants and fruits. The incidence of the disease in the major sesame growing areas ranged from 8 to $92 \%$ (Fula, 2005) which was influenced by various environmental factors like temperature, light, humidity etc. 
Therefore the present study was to study the morphological and cultural characters of the twelve isolates which were collected during the survey in the major sesame growing mandals of Visakhapatnam district during kharif 2016-2017.

\section{Materials and Methods}

\section{Collection of diseased samples}

Leaves of sesame showing typical blight symptoms were collected during the survey conducted and the fungus was isolated by the technique indicated below.

Sesame leaf were cut into small bits with the help of sterilized blade and were surface sterilized with sodium hypochlorite(1\%) for $30 \mathrm{sec}$ followed by three subsequent washings with sterilized distilled water and were blot dried using sterilized blotting paper. The cut samples were then placed on PDA medium in Petri plates. The plates were incubated at $25 \pm$ $1^{0} \mathrm{C}$. Initial growth of the pathogen was subcultured in to Petri plates and well monitored for fungal growth. Pure cultures of all isolates were obtained by single spore method and maintained for further studies.

\section{Morphological variability}

The cultures of isolates were identified based on the characteristics of the colony, hyphae, conidiophore and conidia. Length, breadth and beak length were measured for 45 conidia for each isolate and compared with the dimensions for the A. sesame (Dolle, 1981; Shekarappa, 1999 and Ramegowda and Naik, 2008).

The identity of the fungus was confirmed by comparing the ranges of dimensions derived by the formula given by John (1970)

$\mu=\chi \pm t 0.05 \mathrm{SE}$
Where,

$\sigma=$ Standard deviation

$\mu=$ Population mean

$\chi=$ Sample mean

$\eta=$ Number of spores observed

$\mathrm{t}=$ Table $\mathrm{t}$ value $(\mathrm{P}=0.05)$

$\mathrm{SE}=$ Standard error

\section{Cultural variability}

The isolates were cultured by inoculating 5 $\mathrm{mm}$ culture disc, cut from seven days old culture of $A$. sesami on to the center of the medium in each Petri dish and was incubated at room temperature in three replicates. Radial growth of each fungal isolate was calculated by taking the average of diameter measured on two axes. Other cultural characters like type of growth, colony colour were determined based on the works done by Raja and Reddy (2007), Verma et al., (2007) and Tetarwal et al., (2008).

The growth rate of the fungus on each medium was calculated by the formula given by:

$G R=\frac{S_{X+1}-S_{X}}{T_{X+1}-T_{X}}$

Where, GR = Growth rate $\left(\mathrm{mm} \mathrm{hr}^{-1}\right), \mathrm{S}=$ Colony diameter $(\mathrm{mm}), \mathrm{T}=$ Time $(\mathrm{h})$

Sporulation of each isolate was determined using Neubauer haemocytometer. Spores from each colony were harvested gently by scraping the colony with sterilized inoculation needle in $15 \mathrm{ml}$ of sterile distilled water and the suspension was collected in a test tube. After thorough stirring, spore concentration was adjusted to $10^{4}$ and was determined thrice and the average number of spores $\mathrm{ml}^{-1}$ was estimated for each isolate.

Based on spore concentration per unit area on culture medium isolates were categorized into 
four types i.e., scanty sporulating $\left(<4 \times 10^{4}\right.$ spores $\mathrm{ml}^{-1}$, moderate sporulating $\left(4-8 \times 10^{4}\right.$ spores $\left.\mathrm{ml}^{-1}\right)$, good sporulating $\left(8.1-12 \times 10^{4}\right.$ spores $\left.\mathrm{ml}^{-1}\right)$ and abundant sporulating $(>12 \times$ $10^{4}$ spores $\mathrm{ml}^{-1}$ ) isolates.

\section{Results and Discussion}

\section{Isolation and identification of the pathogen}

The process of isolation resulted in the twelve isolates of the pathogen collected from different regions of Visakhapatnam district. All the isolates were confirmed as of $A$. sesami.

\section{Morphological variability}

In all the twelve isolates the conidia were muriform shape and light brown in color. The length of the conidia varies from 24.88 - 34.64 $\mu \mathrm{m}$. Kokirapalli isolate, KP 2 produced longest $(34.64 \mu \mathrm{m})$ conidia followed by AG 1 $(32.50 \mu \mathrm{m})$ and VP $1(31.55 \mu \mathrm{m})$. The shortest spore producing isolate was AG $2(24.88 \mu \mathrm{m})$ and was followed by EL $1(25.10 \mu \mathrm{m})$. The width of the conidia varies from 9.61-12.13 $\mu \mathrm{m}$. The spore produced by the isolate KP 2 $(12.13 \mu \mathrm{m})$ was found to be the broadest followed by AG $1(12.09 \mu \mathrm{m})$ and while it was least in NP $2(9.61 \mu \mathrm{m})$. Generally all the isolates produced beaked conidia. The beak length of the conidia varied from $5.12-8.32$ $\mu \mathrm{m}$. KP1 had lengthiest beak $(8.32 \mu \mathrm{m})$ followed by KP $2(7.18 \mu \mathrm{m})$ and VP 2 $(7.17 \mu \mathrm{m})$ while shortest beak was observed in AG $2(5.12 \mu \mathrm{m})$. Number of horizontal and vertical septa varied from 2.76 - 3.82 and 1.31 - 1.76 respectively (Table 1). Mohanty and Behera (1958)descriptions were found as references to later works on A. sesami and Leppik and Sowell (1964)stated that his descriptions of $A$. sesami were in conformity with that of Mohanty and Behera. According to Leppik and Sowell (1964), pathogen was reported to have simple, erect, yellowish brown, 0-3 septate conidiophores, measuring 30-50 x 4.5-6.5 $\mu$ mand each bearing conidia singly or in chains at the apex. Conidia were reported to beobclavate, yellowish brown to dark brown that measured 30-100 X 10-28 $\mu \mathrm{m}$, with hyaline beak that was $25-160 \times 2-4 \mu \mathrm{m}$ in size. Dolle (1981) described the conidia of $A$. sesami. Sumathi (1997) reported that the isolates of $A$. sesami produced beaked and unbeaked conidia which were also observed in the present investigation. Shekarappa (1999), Ramegowda and Naik (2008) reported descriptions on the spore size of A. sesami. Savitha et al., (2013) reported the spore dimensions of six isolates of $A$. sesami infecting sesame to range from 14.06-44.40 X 6.62-23.68 $\mu \mathrm{m}$ with maximum beak length of $3.50-17.02 \mu \mathrm{m}$ and the present findings showed conformity with the work.

\section{Cultural variability}

The cultures were identified based on the colony characters and conidial dimensions. Cultures had light gray mycelium which later turned grayish white and developed concentric zonations. The centre of the colony was profuse to fluffy with whitish gray mycelium. Aged culture appeared completely black with no aerial mycelium. Most of the isolates were white in their colony colour that later turned in to grayish brown after seven days of incubation, while a few isolates remained brown since the day of incubation. The isolate KP 2, VP 2were darker than all isolates showing fluffy center with blackish brown flat margin. In majority of the isolates the colony was fluffy, raised at the center with entire margins, while uniform flat colony was noted in isolates NP 1 and EL2 (Table 2). Pigmentation of colonies of Alternaria spp was described to be variable as yellow, brown, black, brownish to greenish black on potato dextrose agar media (Ellis and Gibson, 1975 and Kumar et al., 2008). 
Table.1 Morphological characters of conidia of A. sesami isolates

\begin{tabular}{|c|c|c|c|c|c|c|c|c|c|}
\hline \multirow[t]{2}{*}{ S. No. } & \multirow{2}{*}{ Isolates } & \multicolumn{6}{|c|}{ Spore dimensions $(\mu \mathrm{m})$} & \multicolumn{2}{|c|}{ Number of septa } \\
\hline & & Length & $\begin{array}{l}\text { Population } \\
\text { mean }(\mu \mathrm{m})\end{array}$ & Breadth & $\begin{array}{l}\text { Population mean } \\
\qquad(\mu \mathrm{m})\end{array}$ & $\begin{array}{l}\text { Beak } \\
\text { length }\end{array}$ & $\begin{array}{l}\text { Population } \\
\text { mean }(\mu \mathrm{m})\end{array}$ & $\begin{array}{l}\text { Horizont } \\
\text { al }\end{array}$ & Vertical \\
\hline 1 & $\mathrm{AG} 1$ & 32.50 & $32.50 \pm 2.01(1.16)$ & 12.09 & $12.09 \pm 2.01(0.49)$ & 5.55 & $5.55 \pm 2.01(0.36)$ & 3.48 & 1.55 \\
\hline 2 & $\mathrm{AG} 2$ & 24.88 & $24.88 \pm 2.01(1.16)$ & 11.50 & $11.50 \pm 2.01(0.38)$ & 5.12 & $5.12 \pm 2.01(0.43)$ & 2.76 & 1.36 \\
\hline 3 & KP 1 & 31.10 & $31.1 \pm 2.01(0.57)$ & 9.62 & $9.62 \pm 2.01(0.33)$ & 8.32 & $8.32 \pm 2.01(0.97)$ & 3.06 & 1.44 \\
\hline 4 & KP 2 & 34.64 & $34.64 \pm 2.01(1.24)$ & 12.13 & $12.13 \pm 2.01(0.32)$ & 7.18 & $7.18 \pm 2.01(0.73)$ & 3.40 & 1.73 \\
\hline 5 & VP 1 & 31.55 & $31.55 \pm 2.01(1.13)$ & 10.13 & $10.13 \pm 2.01(0.31)$ & 5.92 & $5.92 \pm 2.01(0.34)$ & 3.57 & 1.48 \\
\hline 6 & VP 2 & 29.16 & $29.16 \pm 2.01(0.99)$ & 10.49 & $10.49 \pm 2.01(0.27)$ & 7.17 & $7.17 \pm 2.01(0.66)$ & 3.13 & 1.42 \\
\hline 4 & NP 1 & 32.10 & $32.10 \pm 2.01(0.90)$ & 11.9 & $11.90 \pm 2.01(0.29)$ & 5.95 & $5.95 \pm 2.01(0.42)$ & 3.02 & 1.64 \\
\hline 8 & NP 2 & 25.20 & $25.20 \pm 2.01(0.68)$ & 9.61 & $9.62 \pm 2.01(0.21)$ & 5.14 & $5.14 \pm 2.01(0.32)$ & 3.02 & 1.31 \\
\hline 9 & EL 1 & 25.10 & $29.2 \pm 2.01(0.84)$ & 11.60 & $11.60 \pm 2.01(0.41)$ & 5.97 & $7.97 \pm 2.01(0.46)$ & 2.90 & 1.36 \\
\hline 10 & EL 2 & 30.31 & $30.1 \pm 2.01(0.90)$ & 11.77 & $11.77 \pm 2.01(0.46)$ & 6.30 & $6.30 \pm 2.01(0.47)$ & 3.40 & 1.57 \\
\hline 11 & NEL 2 & 25.44 & $30.61 \pm 2.01(0.92)$ & 10.33 & $10.33 \pm 2.01(0.38)$ & 5.68 & $5.68 \pm 2.01(0.23)$ & 3.82 & 1.44 \\
\hline \multirow[t]{4}{*}{12} & NAR 1 & 28.89 & $28.89 \pm 2.01(0.74)$ & 11.14 & $11.14 \pm 2.01(0.39)$ & 5.37 & $6.37 \pm 2.01(0.24)$ & 3.22 & 1.76 \\
\hline & SEm \pm & 0.64 & & 0.23 & & 0.17 & & 0.08 & 0.04 \\
\hline & $\mathrm{CD}(\mathrm{P} \leq 0.05)$ & 2.16 & & 0.79 & & 0.59 & & 0.27 & 0.16 \\
\hline & $\mathrm{CV} \%$ & 4.32 & & 4.33 & & 5.54 & & 5.06 & 6.45 \\
\hline
\end{tabular}


Table.2 Cultural characteristics of $A$. sesami isolates after seven days of incubation

\begin{tabular}{|c|c|c|c|}
\hline S. No. & Isolates & Colony colour & Type of growth \\
\hline 1 & AG 1 & White turned to light grayish brown & Fluffy raised center with regular outer margin \\
\hline 2 & AG 2 & White turned to grayish brown & $\begin{array}{l}\text { Cottony fluffy centre with raised light coloured } \\
\text { margin }\end{array}$ \\
\hline 3 & KP 1 & White turned to grayish brown & $\begin{array}{l}\text { Grayish fluffy raised centre with raised whitish } \\
\text { margin }\end{array}$ \\
\hline 4 & KP 2 & White turned to dark grayish brown & Grayish Fluffy centre with brown flat Margin margin \\
\hline 5 & VP 1 & White turned to grayish brown & $\begin{array}{c}\text { Fluffy centre with circular growth grayish white } \\
\text { raised margin }\end{array}$ \\
\hline 6 & VP 2 & Dark brown & Fluffy centre with distinct flat margin \\
\hline 7 & NP 1 & White turned to light brown & Uniform cottony growth with brown regular margin \\
\hline 8 & NP 2 & $\begin{array}{l}\text { Light grayish turned to blackish } \\
\text { brown }\end{array}$ & Fluffy centre with blackish brown flat margin \\
\hline 9 & EL 1 & Light grayish & Fluffy raised centre with grayish raised margin \\
\hline 10 & EL 2 & Light grayish & Cottony growth at centre with whitish raised margin \\
\hline 11 & NEL 2 & White turned to dark brown & Fluffy centre with grayish brown flat margin \\
\hline 12 & NAR 1 & Light grayish turned to dark brown & $\begin{array}{l}\text { Fluffy raised centre with circular growth having flat } \\
\text { margin }\end{array}$ \\
\hline
\end{tabular}

Table.3 Variation in cultural characteristics of $A$. sesame isolates

\begin{tabular}{|c|c|c|c|c|c|c|c|c|c|c|}
\hline \multirow[b]{2}{*}{$\begin{array}{c}\text { S. } \\
\text { No. }\end{array}$} & \multirow[b]{2}{*}{ Isolates } & \multicolumn{7}{|c|}{ Diameter of the colony $(\mathrm{cm})$ DAI } & \multirow[b]{2}{*}{ Mean } & \multirow{2}{*}{$\begin{array}{l}\text { Spore } \\
\text { conc } \\
X 10^{4}\end{array}$} \\
\hline & & $1^{\text {st }}$ day & $2^{\text {nd }}$ day & $3^{\text {rd }}$ day & $4^{\text {th }}$ day & $5^{\text {th }}$ day & $6^{\text {th }}$ day & $7^{\text {th }}$ day & & \\
\hline 1 & AG 1 & 0.60 & 0.83 & 1.47 & 2.22 & 2.78 & 3.42 & 4.08 & 2.2 & 5.33 \\
\hline 2 & AG 2 & 0.53 & 0.97 & 1.22 & 2.33 & 2.97 & 3.58 & 4.13 & 2.24 & 11.33 \\
\hline 3 & KP 1 & 0.72 & 1.08 & 1.53 & 2.53 & 3.10 & 3.77 & 4.48 & 2.45 & 16.67 \\
\hline 4 & KP 2 & 0.63 & 1.13 & 1.43 & 2.33 & 2.98 & 3.98 & 5.07 & 2.50 & 11.67 \\
\hline 5 & VP 1 & 0.80 & 1.18 & 1.62 & 2.30 & 3.10 & 4.12 & 5.12 & 2.60 & 28.33 \\
\hline 6 & VP 2 & 0.83 & 1.17 & 1.52 & 2.58 & 3.08 & 4.18 & 5.08 & 2.63 & 44.67 \\
\hline 7 & NP 1 & 0.87 & 1.23 & 1.63 & 2.67 & 3.12 & 4.18 & 5.25 & 2.70 & 71.67 \\
\hline 8 & NP 2 & 0.87 & 1.18 & 1.72 & 2.83 & 3.23 & 4.15 & 5.28 & 2.75 & 41.00 \\
\hline 9 & EL 1 & 0.80 & 1.08 & 1.53 & 2.50 & 2.98 & 4.12 & 5.12 & 2.59 & 17.67 \\
\hline 10 & EL 2 & 0.62 & 1.03 & 1.58 & 2.62 & 3.18 & 4.02 & 5.27 & 2.61 & 20.67 \\
\hline 11 & NEL2 & 0.83 & 1.28 & 1.75 & 2.82 & 3.22 & 4.12 & 5.12 & 2.73 & 39.00 \\
\hline \multirow[t]{4}{*}{12} & NAR 1 & 0.90 & 1.27 & 1.78 & 2.87 & 3.08 & 4.08 & 5.27 & 2.75 & 52.67 \\
\hline & SEm \pm & 0.014 & 0.021 & 0.027 & 0.016 & 0.020 & 0.020 & 0.027 & & 1.11 \\
\hline & $\begin{array}{c}\text { CD } \\
(\mathrm{P} \leq \mathbf{0 . 0 5})\end{array}$ & 0.04 & 0.06 & 0.07 & 0.04 & 0.05 & 0.05 & 0.08 & & 2.92 \\
\hline & CV \% & 5.66 & 5.75 & 5.18 & 1.90 & 1.95 & 1.52 & 1.67 & & 11.04 \\
\hline
\end{tabular}


Table.4 Growth rate of different $A$. sesami isolates

\begin{tabular}{|c|c|c|c|c|c|c|c|c|}
\hline $\begin{array}{c}\text { S. } \\
\text { No. }\end{array}$ & Isolates & \multicolumn{7}{|c|}{ GROWTH RATE (per day) } \\
\hline $\mathbf{1}$ & AG 1 & $\mathbf{1}^{\text {st }} \mathbf{d a y}$ & $\mathbf{2}^{\text {nd }} \mathbf{d a y}$ & $\mathbf{3}^{\text {rd }} \mathbf{d a y}$ & $\mathbf{4}^{\text {th }} \mathbf{d a y}$ & $\mathbf{5}^{\text {th }} \mathbf{d a y}$ & $\mathbf{6}^{\text {th }} \mathbf{d a y}$ & $\mathbf{7}^{\text {th }}$ day \\
\hline $\mathbf{2}$ & AG 2 & 0.01 & 0.01 & 0.03 & 0.03 & 0.02 & 0.03 & 0.03 \\
\hline $\mathbf{3}$ & KP 1 & 0.02 & 0.02 & 0.01 & 0.05 & 0.03 & 0.03 & 0.02 \\
\hline $\mathbf{4}$ & KP 2 & 0.01 & 0.02 & 0.02 & 0.04 & 0.02 & 0.03 & 0.03 \\
\hline $\mathbf{5}$ & VP 1 & 0.02 & 0.02 & 0.02 & 0.04 & 0.03 & 0.04 & 0.05 \\
\hline $\mathbf{6}$ & VP 2 & 0.02 & 0.01 & 0.01 & 0.04 & 0.03 & 0.04 & 0.04 \\
\hline $\mathbf{7}$ & NP 1 & 0.02 & 0.02 & 0.02 & 0.04 & 0.02 & 0.05 & 0.04 \\
\hline $\mathbf{8}$ & NP 2 & 0.02 & 0.01 & 0.02 & 0.05 & 0.02 & 0.04 & 0.04 \\
\hline $\mathbf{9}$ & EL 1 & 0.02 & 0.01 & 0.02 & 0.04 & 0.02 & 0.05 & 0.05 \\
\hline $\mathbf{1 0}$ & EL 2 & 0.01 & 0.02 & 0.02 & 0.04 & 0.02 & 0.03 & 0.04 \\
\hline $\mathbf{1 1}$ & NEL 2 & 0.02 & 0.02 & 0.02 & 0.04 & 0.02 & 0.04 & 0.04 \\
\hline $\mathbf{1 2}$ & NAR 1 & 0.03 & 0.02 & 0.02 & 0.05 & 0.01 & 0.04 & 0.05 \\
\hline
\end{tabular}

Table.5 Correlation between radial growth, growth rate, spore concentration and PDI

\begin{tabular}{|l|r|r|r|r|}
\hline & $\begin{array}{c}\text { RADIAL } \\
\text { GROWTH }\end{array}$ & $\begin{array}{c}\text { GROWTH } \\
\text { RATE }\end{array}$ & $\begin{array}{c}\text { SPORE } \\
\text { CONC }\end{array}$ & PDI \\
\hline RADIAL GROWTH & 1.000 & & & \\
\hline GROWTH RATE & 0.935 & 1.000 & & \\
\hline SPORE CONC & 0.641 & 0.496 & 1.000 & 1.000 \\
\hline PDI & 0.366 & 0.368 & 0.370 & r value $=1.79$ \\
\hline
\end{tabular}

Fig.1 Radial growth of different A. sesami isolates on different days of incubation

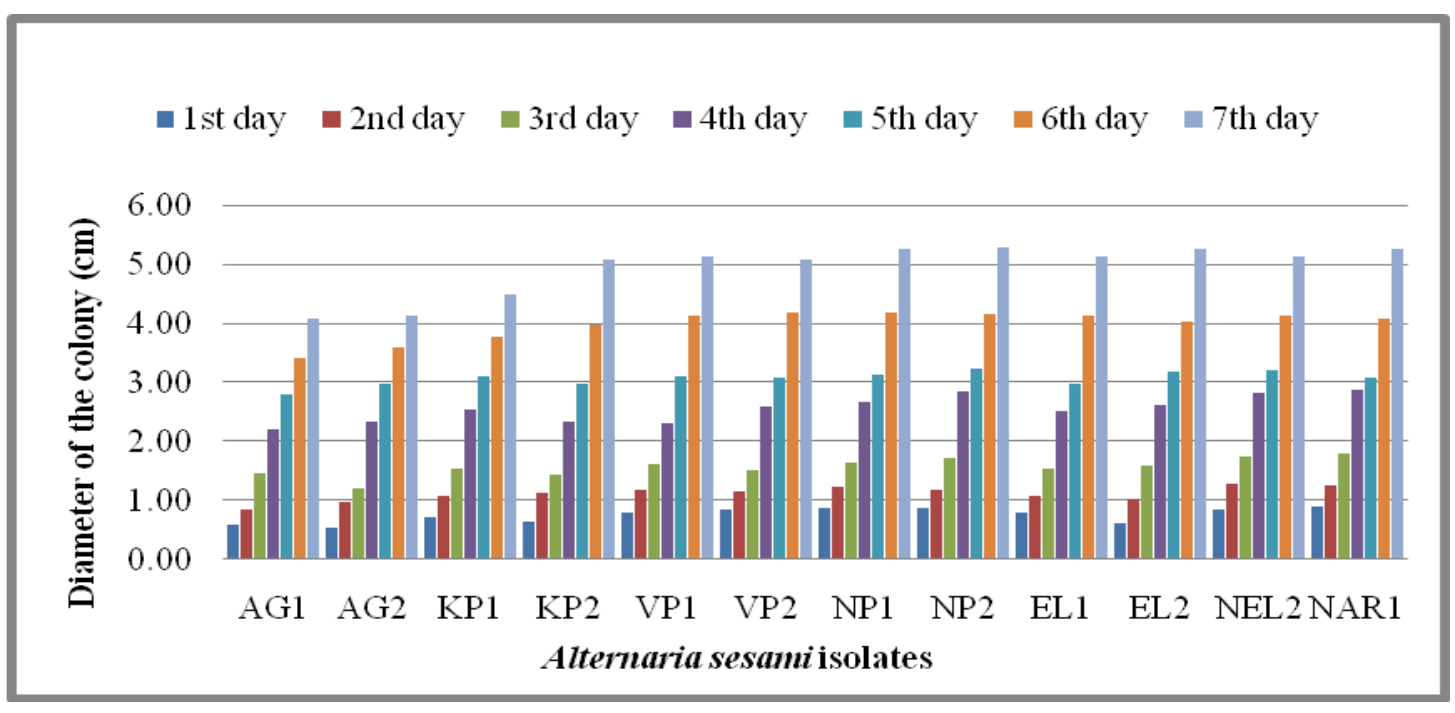


Fig.2 Growth rate of different isolates of A. sesami on different days of incubation

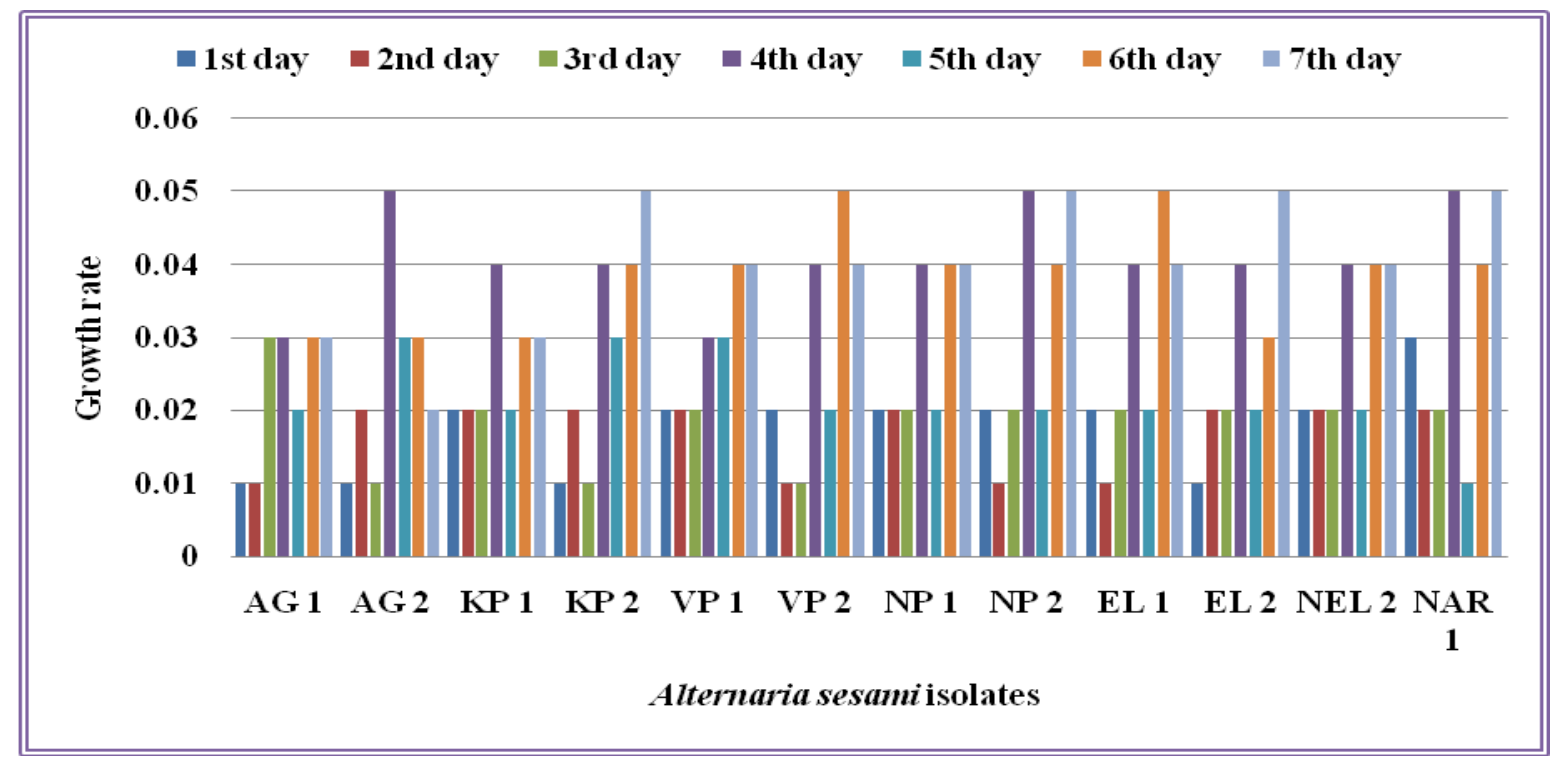

Rotem (1994) stated that variation in the cultural characteristics (colour, growth and sporulation) makes it possible to find as many races as possible in all isolates Variation in colony margin was described as serrated, wavy and entire (Nagrale et al., 2013).

Radial growth of $A$. sesame isolates on PDA significantly differed among the twelve isolates tested $(4.08-5.28 \mathrm{~cm}$ ) (Table 3 and Fig. 1). Savitha et al., (2013) reported that radial growth of $A$. sesami isolates to range between 3.5 and $8.8 \mathrm{~cm}$ when cultured on different media like PDA, host extract agar, oat meal agar, Czapeck's agar, Sabourd's agar and Richard's agar and the present results ascertain the previous report.

Growth rate among the isolates varied from 0.01 to 0.05 in seven days of incubation (Table 4 and Fig. 2). Sporulation in A. sesame isolates after seven days of incubation varied from $5.33 \times 10^{4}$ (AG 1) to $71.67 \times 10^{4} \mathrm{ml}^{-1}$ (NP 1). NP1 isolate was actively sporulating among all the isolates. AG 1 isolate was found to have moderate sporulation, two isolates AG 2 and KP 2 had good sporulation while most of the other isolates were found to produce abundant sporulation (Table 3). Nagrale et al., (2013) found varied spore concentration in Gerbera A. alternata isolates when tested on 20 different media ranged from $0.02 \times 10^{4} \mathrm{~cm}^{-2}$ (Tap water) to $0.61 \times 10^{4}$ $\mathrm{cm}^{-2}$ (PDA) which were exactly corresponding with the results of Kapoor and Hingorani (1958); Lonnaidis and Main (1973) Variation in sporulation of $A$. solani isolates on PDA was reported by Singh et al., (2014) who observed sporulation in only two of 10 isolates to range from $0.5 \times 10^{3}$ to $2.0 \times 10^{3} \mathrm{ml}^{-}$ ${ }^{1}$ when the inoculated petri plates were kept in BOD at $25 \pm 2{ }^{0} \mathrm{C}$ for growth.

Significant positive correlation was found between radial growth and growth rate (0.935) while non-significant but positive correlation was observed between radial growth and PDI (0.366) and growth rate and PDI (0.368) (Table 5).

The present findings clearly indicate significant variability in the cultural characters of twelve isolates of A. sesami. Sporulation was abundant on the PDA media. Similar type of observation was taken by Rajender et al., (2013) in A. helianthi. The 
radial growth of the pathogen increased from the day of incubation on the PDA media. Variation in growth of $A$. solani on PDA was reported (Tong et al., 1994; Babu et al., 2000; Kumar et al., 2008; Naik et al., 2010; Singh et al., 2014 and Nikam et al., 2015). Pachori et al., (2016) reported that average mycelial growth rate of $A$. solani isolates after seven DAI to range between $29.5 \mathrm{~mm}$ to $35.5 \mathrm{~mm}$.

The colour of the colonies were light gray in the beginning and turned to grayish white with concentric zonations and the aged culture was completely black with no aerial mycelium which was in corroboration with Rotem (1994) stated that variation in the cultural characteristics (colour, growth and sporulation) makes it possible to find as many races as possible in all isolates.

Pigmentation of the colonies of the isolates varied from yellow, brown, brownish to greenish black on PDA. Spore production was abundant for most of the isolates. The present findings were in corroboration with variation in sporulation of $A$. solani isolates on PDA was reported by Singh et al., (2014) who observed sporulation in only two of 10 isolates when the inoculated petri plates were kept in BOD at $25 \pm 2{ }^{0} \mathrm{C}$ for growth. In contrast to the above findings in the present study all isolates sporulated when incubated at room temperature with alternate cycles of light and darkness. It was reported that light to have a profound influence on growth and sporulation of fungi (Padhi and Rath, 1974; Naik et al., 2010).

The measurements of the conidia varied for different isolates when grown on the PDA medium. The conidial dimensions in the present study are in agreement with the earlier descriptions of Leppik and Sowell (1964). Dolle (1981) described the conidia of $A$. sesami. Sumathi (1997) reported that the isolates of $A$. sesami produced beaked and unbeaked conidia which were also observed in the present investigation. Shekarappa (1999), Ramegowda and Naik (2008) reported descriptions on the spore size of A. sesami. Savitha et al., (2013) reported the spore dimensions of six isolates of $A$. sesami infecting sesame to range from 14.06-44.40 X $6.62-23.68 \mu \mathrm{m}$ with maximum beak length of 3.5-17.02 $\mu \mathrm{m}$.

\section{Acknowledgement}

The authors are greatful to Assistant Professor RARS, Anakapalle for constant encouragements, valuable suggestions in this research.

\section{References}

Babu, S., Seetharaman, K., Nandakumar, R and Johnson, I. 2000.Variability in cultural characters of tomato early blight pathogen. Plant Disease Research. 15: 121

Bhale, M.S., Bhale, U and Khare,M.N. 1998. Diseases of important oilseed crops and their management. In: S. M. P. Khurana (ed.). Pathological Problems of Economic Crop Plants and their Management. Scientific Publishers, India.251-279.

Department of Agriculture, Cooperation \& Farmers Welfare, Government of India, 2016-17. www.nmoop.gov.in.

Dolle, V.V. 1981. Studies on Alternaria leaf blight of sesame caused by Alternaria sesami (Kawamura) Mohanty and Behera. M.Sc. (Agri.) Thesis, University of Agricultural Sciences, Bangalore, 91.

Ellis, M.B and Gibson, I.A.S. 1975. Alternaria solani no. 45 set 48. Commonwealth Mycological Institute, Kew, Surrey, UK.

Fula, A.L. 2005. Epidemology and management of blight (Alternaria alternate (Fr.) Keissler) of sesame 
(Sesamum indicum L.). PhD (Ag.) Thesis, Junagadh Agricultural University, Junagadh, Gujarat.

John, E.F. 1970. Statistics - A first course. Prentice Hall Inc. Englewood Cliffs, New Jersey. 204.

Kapoor, J.N and Hingorani, M.K. 1958. Alternaria leaf spot and fruit rot of brinjal. Indian Journal of Agricultural Science.28: 109- 114.

Kolte, S.J.1985. Diseases of Annual Edible Oilseed Crops. Rapeseed-mustard and sesame diseases. CRC Press, Inc. Florida.2: 135.

Kumar, V., Haldar, S., Pandey, K.K., Singh, R.P., Singh, A.K and Singh, P.C. 2008. Cultural, morphological, pathogenic and molecular variability amongst tomato isolates of A. solani in India. World Journal of Microbiology and Biotechnology. 24: 1003-1009.

Leppik, E.E and Sowell, G. Jr. 1964. Alternaria sesami, a serious seed borne pathogen of world wide distribution FAO. Plant Protection Bulletin 12: 1316.

Lonnaidis, N.M and Main, C.E. 1973. Effect of culture medium on production and pathogenicity of Alternaria alternata conidia. Plant Disease Repoter. 57 (1): $39-42$

Mohanty, N.N and Behera, B.C. 1958. Blight of Sesame (Sesamum orientale L.). Caused by Alternaria sesame Kaw. Current Science. 27: 492-493.

Nagrale, D.T., Gaikwad, A.P and Sharma, L. 2013. Morphological and cultural characterization of Alternaria alternate (Fr.) Keissler blight of gerbera (Gerbera jamesonii H. Bolus ex J.D. Hook). Journal of Applied and Natural Science.5(1): 171-178

Naik, M.K., Prasad, Y., Bhat, K.V and Rani, D.G.S. 2010.Morphological, physiological, pathogenic and molecular variability among isolates of Alternaria solani from tomato. Indian Phytopathology. 63 (2): 168-173.

Nikam, P.S., Suryawanshi, A.P and Chavan, A.A. 2015.Pathogenic, cultural, morphological and molecular variability among eight isolates of Alternaria solani, causing early blight of tomato. African Journal of Biotechnology. 14(10): 872-877.

Ojiambo, P.S., Mibey, R.K., Narla, R.D and. Ayiecho, P.O. 2003. Field transmission efficiency of Alternaria sesami in sesame from infected seed. Crop Protection. 22(9): 1107-1115

Pachori, A., Sharma, O., Sasode, R and Sharma, R.N. 2016.Collection of different isolates of Alternaria solaniin Bhind, Morena and Gwalior districts of Madhya Pradesh.International Journal of Applied Research. 2(6): 217- 219

Padhi, N.N and Rath, G.C 1973.Sporulation of Alternaria solani in pure culture. Indian Phytopathology. 26:495-501.

Raja, P. Reddy, A.V and Ramama. 2007. Morphological and biological variability of Alternaria spp. causing leaf spot and fruit rot of brinjal. Journal of Mycology and PlantPathology.37 (2): 336-338

Ramegowda, G and Naik, M.K. 2008. Morphological, cultural and physiological diversity in isolates of Alternaria spp. infecting btcotton.Journal of Mycology and Plant Pathology.38: 2008.

Rotem, J. 1994. The genus Alternaria. Biology, epidemiology and pathogenicity. APS press. USA.

Savitha, A.S., Naik, M.K and Kumar, K.A. 2013.Cultural, morphological, physiological and pathogenic diversity among the isolates of Alternaria spp. incitant of blight disease of sesame. Journal of Mycopathology. 51(2): 256265.

Shekarappa, G. 1999. Studies on foliar 
diseases of sesame.M.Sc. (Ag) Thesis, University of Agricultural Sciences, Dharwad. 109.

Singh, A., Singh, V and Yadav, S.M. 2014. Cultural, morphological and pathogenic variability of Alternaria solani causing early blight in tomato. Plant Pathology Journal.1-6.

Sumathi, P. 1997. Biological management of sesame (Sesamum indicum L.) caused by Alternaria sesami (kavam). Mohanty and Behera, M.Sc (Ag) Thesis, Tamil Nadu Agricultural University, Coimbatore, India.

Tetarwal, M. L., Rai P.K and Shekhawat, K.S. 2008.Morphological and pathogenic variability of Alternaria infecting senna. Journal of Mycology and Plant
Pathology. 38 (2): 375-37

Tong, Y.H., Liang, $\mathrm{J}$ and Jing X.Y. 1994.Study on the biology and pathogenicity of Alternaria solani on tomato. J Jiangsu Agricultural college. 15 (3): 29-31.

Verma, M.L., Mehta, N., and Sangwan, M.S. 2005.Fungal and bacterial diseases of sesame. In: G. S. Saharan, N. Mehta and M. S. Sangwan (ed.). Diseases of Oilseed Crops.Indus Publishing, New Delhi, India.269-303.

Verma, P.K., Singh, S and Gandhi, S.K. 2007. Variability among Alternaria solani isolates causing early blight of tomato. Indian Phytopathology. 60 (2): 180-186.

\section{How to cite this article:}

Vulimiri Jyothsna, V. Prasanna Kumari, V. Manoj Kumar and Sreekanth, B. 2018. Morphological and Cultural Characterization of Isolates of Alternaria sesami Causing Sesame Leaf Blight. Int.J.Curr.Microbiol.App.Sci. 7(11): 1937-1946.

doi: https://doi.org/10.20546/ijcmas.2018.711.220 